\title{
Population census of Thornicroft's giraffe Giraffa camelopardalis thornicrofti in Zambia, 1973-2003: conservation reassessment required
}

\author{
Philip S. M. Berry and Fred B. Bercovitch
}

\begin{abstract}
Thornicroft's giraffe Giraffa camelopardalis thornicrofti is limited in distribution to a single population resident in the Luangwa Valley, Zambia. During 1973-2003 regular counts were recorded along the Luangwa River in the core section of the subspecies' range. In 2013 we conducted a count in the same region for comparison with the earlier survey results. During the 30-year period 1973-2003 the giraffe index (no. of individuals per km surveyed) was relatively stable, with an increase in 1994 and 1995 coinciding with an influx of giraffes to the west bank following an exceptionally reduced flow of the Luangwa River. The mean giraffe index during this period was $0.51 \mathrm{~km}^{-1}$, whereas the 2013 count yielded an index of $0.44 \mathrm{~km}^{-1}$. Given the limited range of the Thornicroft's giraffe, we estimate that the population comprises c. 500-600 individuals.
\end{abstract}

Keywords Giraffe, Giraffa camelopardalis, population census, Thornicroft's giraffe, Zambia

Thornicroft's giraffe Giraffa camelopardalis thornicrofti I is an isolated subspecies (Dagg, 2014; but see Groves \& Grubb, 2011) found only in the Luangwa Valley, in eastern Zambia. Current information regarding their mitochondrial DNA profile indicates that the Thornicroft's giraffe is more similar to the Masai giraffe G. camelopardalis tippelskirchi than to any of the other subspecies (Fennessy et al., 2013). However, the Masai giraffe is found at least $300 \mathrm{~km}$ north of the Thornicroft's giraffe and there are no records of movement between the two populations.

The Luangwa Valley is traversed along a north-south axis by the Luangwa River, a meandering waterway characterized by numerous oxbow lakes, or lagoons, and delineated on the western side by the Muchinga Escarpment. The northern limits of the Thornicroft's giraffe are uncertain but its range extends at least to the confluence of the Chibembe and Luangwa Rivers (c. $12^{\circ} 50^{\prime} \mathrm{S}$ ). Similarly, the

Philip S. M. Berry P.O. Box 33, Mfuwe, Zambia

Fred B. Bercovitch (Corresponding author) Primate Research Institute and Wildlife Research Centre, Kyoto University, Inuyama, Japan

E-mail bercovitch.fred.2u@kyoto-u.ac.jp

Received 29 June 2015. Revision requested 29 September 2015

Accepted 29 October 2015. First published online 20 January 2016. southern limit is unknown but reaches the confluence of the Msanzara and Luangwa Rivers (c. $13^{\circ} 45^{\prime} \mathrm{S}$ ). Individuals range primarily along the Luangwa River, usually within 2-3 km, although occasionally up to $7 \mathrm{~km}$ away (Berry, 1978). Areas further from the Luangwa River are mostly unsuitable, especially the miombo (Brachystegia and Julbernardia) woodland, where the giraffes' main food plants are scarce or non-existent.

The habitat most favoured by the giraffe is riparian forest containing a number of large tree species that feature prominently in their diet (e.g. Trichilia emetica, Tamarindus indica, Diospyros mespiliformis, Faidherbia albida, Kigelia africana). Other habitats include mopane Colophospermum mopane and munga (Acacia, Combretum, Terminalia) woodland, thickets, scrub brush and open grassland (Astle et al., 1969; Fanshawe, 1969; Berry, 1973). Giraffes subsist on a varied diet, consuming flowers, leaves, stems and fruits from 93 plant species in the Luangwa Valley (Berry, 1973; P.S.M. Berry \& F.B. Bercovitch, unpubl. data). In 1938 their core area was given protection with the gazetting of the South and North Luangwa Game Reserves, both of which were designated National Parks in 1972.

In the early 1900 s the population was estimated to comprise only 30-70 individuals, mostly ranging on the eastern bank of the Luangwa River in small herds, but the methods used to determine these estimates are unknown and probably reflected the impressions of the early British administrators (Berry, 1973). One report of $>500$ giraffes in the 1920 s appears to be inaccurate, based on subsequent information (Berry, 1973). Darling (1960) estimated a population of 200250 individuals along the eastern bank of the river at c. $13-14^{\circ} \mathrm{S}$, although he also recorded a few 'vagrants' on the western bank. By the end of the 196os the range of the Thornicroft's giraffe had expanded in both northerly and southerly directions (Berry, 1973). Berry (1973) noted that a few individuals were present on the western bank but most of the population lived on the eastern bank. The greatest north-south distance between sightings of Thornicroft's giraffe was between $11^{\circ} 50^{\prime} \mathrm{S}$ and $14^{\circ} 18^{\prime} \mathrm{S}$, but these were often either lone bulls or small herds. In 1969 Berry (1973) estimated a population size of 270-300, with Dagg \& Foster (1982) concurring that the maximum population size was c. 300 individuals.

Systematic population surveys were initiated in 1973 by PSMB. Giraffes have distinctive coat patterns that remain 
unchanged throughout their lifetime and facilitate identification of individuals. Here we present giraffe population trends that cover a 30-year span (1973-2003), as well as results from a follow-up survey in 2013. During 1973-2003 surveys were conducted annually on foot and/or in a vehicle. Each time a giraffe was observed its identity, if known, was recorded, along with location, herd composition, time and activity. As identical methods were used throughout this period, the population counts are comparable across years, although they may not be directly comparable with those at other sites where alternative methods were used. The counts were conducted along both the east and west banks of the Luangwa River but for consistency across years we restrict our analysis to the west bank, as those surveys were undertaken on a more regular basis. In 1994 and 1995 the Luangwa River stopped flowing in some places and giraffes of both sexes and all ages were able to cross dry sections of the river bed from the east to the west bank. This resulted in an influx of new giraffes into the study area. Prior to that time only mature bulls were capable of wading across the Luangwa River.

For purposes of analysis we subdivided the 30-year study into 5-year time blocks. The total number of giraffes counted during each survey year analysed included both recognized and unknown individuals. For each year we calculated the mean number of sightings of known individuals. We then divided the number of counts of unknown individuals by this mean to estimate the total number of unrecognized giraffes observed in the survey area. We added the numbers of identified and unrecognized giraffes to yield a total count. For example, in 1988 we recorded 28 unique individuals on 249 occasions, or a mean of 8.9 observations per individual. The same year we counted unknown giraffes on 92 occasions, which we estimate represented 10 individuals (92/ $8.9=10.3)$. Combining these numbers yields a total count of 38 giraffes along the $90 \mathrm{~km}$ survey. Given that we have no estimate of distance from the survey track to the giraffes, we cannot estimate density and therefore we refer to our values as a giraffe index.

The survey distance was determined by measuring the length of travel during each of the survey years on maps of scale 1:50,000 produced by the Department of Surveys of the Republic of Zambia. The maps used in our assessment were 1331 B1 (Manze), 1331 B2 (Mfuwe), 1331 B3 (Lusangazi), $1232 \mathrm{C}_{3}$ (Chasera) and $1231 \mathrm{D}_{4}$ (Lion Plain). Figure 1 shows the location of the survey region, the approximate range of the Thornicroft's giraffe and the distance to the closest subspecies of giraffe.

In September 2013 a more directed and focused systematic count was conducted by PSMB, FBB and colleagues in the South Luangwa National Park. Over a 6-day period, teams of 2-5 trained observers drove along tracks in the Park and recorded the number of giraffes observed, as well as specific coat patterns for recognition of individuals. During a 4-day period (4-7 September 2013) we

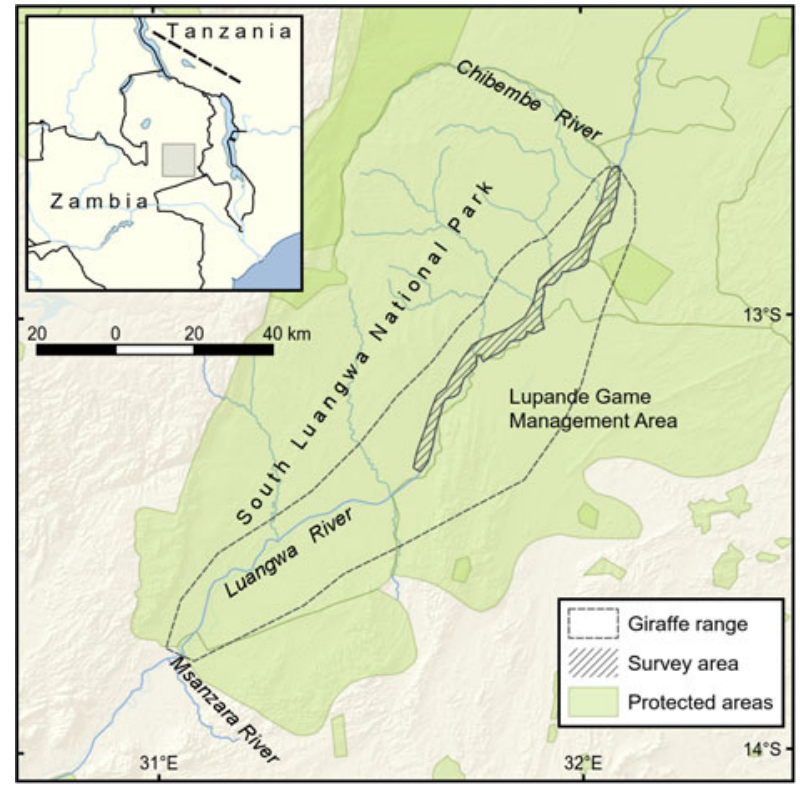

FIg. 1 The area within South Luangwa National Park, Zambia, surveyed for the Thornicroft's giraffe Giraffa camelopardalis thornicrofti, and the presumed range of the subspecies The southern limit of the Masai giraffe G. camelopardalis tippelskirchi, the nearest subspecies, is indicated by the dashed line on the inset.

concentrated on the roads in the vicinity of Mfuwe Lodge. This survey covered $67.9 \mathrm{~km}$ and we counted a minimum of 26 individual giraffes, yielding an index of $0.38 \mathrm{~km}^{-1}$. On 10 September 2013 we identified 40 individuals during a systematic survey that covered $75 \mathrm{~km}$ of road not in the vicinity of Mfuwe Lodge. This survey yielded a giraffe index of $0.53 \mathrm{~km}^{-1}$. The last count was conducted on 12 September 2013 during a drive of $17.5 \mathrm{~km}$. Seven individuals were sighted during this survey, yielding a giraffe index of $0.40 \mathrm{~km}^{-1}$. Hence, during the 6-day survey the giraffe index was $0.38-0.53 \mathrm{~km}^{-1}$, with a mean of $0.44 \mathrm{~km}^{-1}$.

Figure 2 charts the giraffe index within the Luangwa River Valley during 1973-2003. Because of the relatively small population size, demographic changes have a significant impact on density estimates. The dip in 1983 was probably a result of the deaths of two mature males in August, one of whom was the victim of lion Panthera leo predation. Over the 30-year period the mean giraffe index was $0.51 \pm \mathrm{SE}$ $0.10 \mathrm{~km}^{-1}$. Omitting the two unusual years of 1983 and 1998 gives a mean index of $0.48 \pm \mathrm{SE} 0.04 \mathrm{~km}^{-1}$. The giraffe index in $1973\left(0.42 \mathrm{~km}^{-1}\right)$ was essentially the same as in 2013 $\left(0.44 \mathrm{~km}^{-1}\right)$.

With an estimated giraffe index in 2013 of $0.44 \mathrm{~km}^{-1}$ along the Luangwa River, and given an approximate length of $250 \mathrm{~km}$ for the Luangwa River between the confluence with the Chibembe River and the confluence with the Msanzara River, we can reasonably assume that at least 110 Thornicroft's giraffes reside in their core area along 


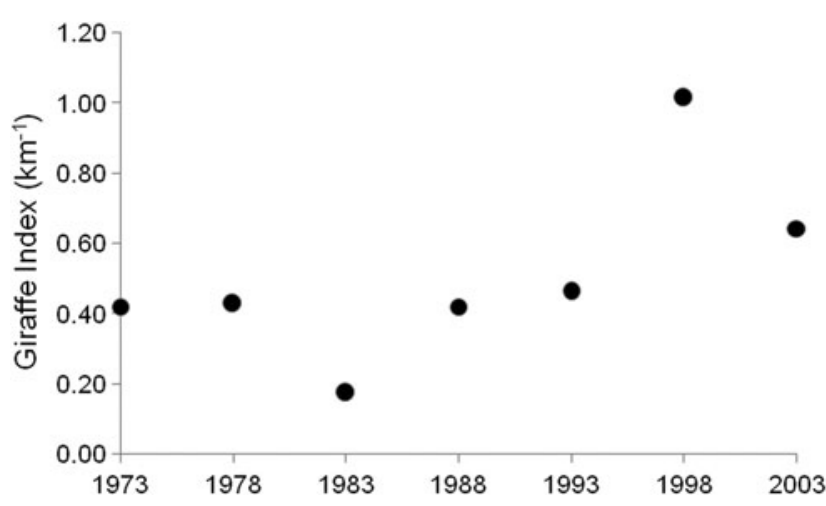

FIG. 2 The population trend of the Thornicroft's giraffe in its core range in the Luangwa Valley, Zambia (Fig. 1), during 1973-2003.

the tracks near the Luangwa River. Given that giraffes rarely range outside of the alluvial zone or $>3 \mathrm{~km}$ from a river (Berry, 1978), a maximum of 660 Thornicroft's giraffes can be estimated to live in their core range within the Luangwa River Valley. However, giraffe distribution is not uniform along the river, suggesting that the total population size is probably somewhat less than our estimates. We therefore conclude that the total population is probably $500-600$.

The size of the Thornicroft's giraffe population in the Luangwa River Valley has been reasonably stable over the past 40 years. Giraffes are concentrated on the west bank, with changes in population distribution coinciding with the extent of water flow in the Luangwa River. Currently G. camelopardalis is categorized as a species of Least Concern on the IUCN Red List (Fennessy \& Brown, 2010), although two subspecies (G. camelopardalis peralta and G. camelopardalis rothschildi) are categorized as Endangered (Fennessy \& Brown, 2008; Fennessy \& Brenneman, 2010). Given that the Thornicroft's giraffe is confined to a single location in a protected area of Zambia, with the total population size estimated to be 600 or fewer, we strongly recommend a reassessment of the conservation status of G. camelopardalis thornicrofti, and urge that conservation monitoring of this distinctive subspecies be implemented for its continued protection.

\section{Acknowledgements}

Our work has been supported by Andy Hogg (Bushcamp Company), and giraffe data were collected with the support of the Government of Zambia. Our examination of the longitudinal database was triggered by extensive communication with Kerryn Carter, Julian Fennessy and Andy Tutchings, all of whom provided insightful input.

\section{References}

Astle, W.L., Webster, R. \& Lawrance, C.J. (1969) Land classification for management planning in the Luangwa Valley of Zambia. Journal of Applied Ecology, 6, 143-169.

Berry, P.S.M. (1973) The Luangwa Valley giraffe. Puku, 7, 71-92.

BERRY, P.S.M. (1978) Range movements of giraffe in the Luangwa Valley, Zambia. African Journal of Ecology, 16, 77-83.

DAGG, A.I. (2014) Giraffe: Biology, Behaviour, and Conservation. Cambridge University Press, Cambridge, UK.

DAgG, A.I. \& Foster, J.B. (1982) The Giraffe: Its Biology, Behavior and Ecology, 2nd edition. Krieger Publishing Co., Malabar, USA.

Darling, F.F. (1960) Wild Life in an African Territory. Oxford University Press, Oxford, UK.

Fanshawe, D.B. (1969) The Vegetation of Zambia. Forest Research Bulletin, Publication No. 7. Government Printers, Lusaka, Zambia.

Fennessy, J., Bock, F., Tutchings, A., Brenneman, R. \& Janke, A. (2013) Mitochondrial DNA analyses show that Zambia's South Luangwa Valley giraffe (Giraffa camelopardalis thornicrofti) are genetically isolated. African Journal of Ecology, 51, 635-640.

Fennessy, J. \& Brown, D. (2008) Giraffa camelopardalis ssp. peralta. In The IUCN Red List of Threatened Species 2008: e.

T136913A4349726. Http://dx.doi.org/10.2305/IUCN.UK.2008.RLTS. T136913A4349726.en [accessed 13 November 2015].

Fennessy, J. \& BRENneman, R. (2010) Giraffa camelopardalis ssp. rothschildi. In The IUCN Red List of Threatened Species 2010: e. T174469A7077893. Http://dx.doi.org/10.2305/IUCN.UK.2010-2. RLTS.T174469A7077893.en [accessed 13 November 2015].

Fennessy, J. \& Brown, D. (2010) Giraffa camelopardalis. In The IUCN Red List of Threatened Species 2010: e.T9194A12968471. Http:// dx.doi.org/10.2305/IUCN.UK.2010-2.RLTS.T9194A12968471.en [accessed 7 August 2014].

Groves, C. \& Grubb, P. (2011) Ungulate Taxonomy. Johns Hopkins University Press, Baltimore, USA.

\section{Biographical sketches}

Philip BerRy has been studying the natural history of Zambia for over 50 years. He was the Chief Ranger for the Department of Wildlife, Fisheries and National Parks, led anti-poaching patrols for Save the Rhino Trust, and has been a safari guide in the Luangwa Valley for decades. Fred BerCovitch specializes in wildlife biology and has conducted research on baboons in Kenya, rhesus monkeys in Puerto Rico, elephants in Botswana, and koalas in Australia, as well as giraffe in Zambia. 